\title{
CREATIVE AND CRITICAL THINKING IN AN AGE OF COMPLEXITY - KEY SKILLS FOR MILITARY COMMANDERS
}

\author{
Andreas ALEXA \\ National Defence Academy, Vienna, Austria \\ andreas.alexa@bmlv.gv.at
}

\begin{abstract}
This article discusses the need of creative and critical thinking for military commanders. These skills are preconditions for success due to the nowadays complex environment, in which military operations are conducted. Military commanders in the age of complexity should and must therefore critically examine their actions with regard to the achievement of objectives. The subsequent creative process leads to innovation and thus to a further development of their own field of expertise and the Armed Forces. Therefore, these capabilities must be implemented in the officer's education system.
\end{abstract}

KEYWORDS: creative thinking, critical thinking, complexity, education, military science

\section{Introduction}

The Austrian trend researcher and futurologist Henry Gatterer noted, "That the world tends towards complexity" (Gatterer, 2017). The conclusion to be drawn from this is that linear thinking is no longer state-of-the-art and must be replaced by creative and critical thinking. Because the military finds itself in this complex world as an instrument of state power, it is logical to train military commanders in creative and critical thinking. However, what constitutes creative and critical thinking today, and how can it be implemented in command training at military educational and training institutions? This article explores these and other questions and aims to highlight the importance of creative and critical thinking for military commanders. The main method used was a review of the relevant literature, supported by an empirical observation at the Master's Program in Military Leadership.

It begins with a closer look at the military and complexity and then examines creative or critical thinking in order to draw conclusions for the education and training of military commanders.

\section{Military and Complexity}

In principle, the military will always be deployed if and when other instruments or means of a state or society are no longer sufficient to achieve the set goals. The fundamental means of a state are the so-called instruments of national power, which comprise the areas of diplomacy, information, military, and economy (Farlin, 2014). It is also necessary to consider the significant interdependencies between these different instruments. 
The military is thus only one option when enforcing the will of the state, i.e., a society's political system capable of fulfilling political ends in a specific way, namely by adding organized force (Kümmel, 2006). It is thus both the exclusive and ultimate means of a state or society to ensure the state's ability to act and, ultimately, its survival. Armed forces are the concrete manifestation of the military (Bousquet, 2009). They are dynamic, not static, entities, as their appearance and character permanently change in parallel with the societies they serve. Armed forces are established, paid, and deployed exclusively in the name of and for the purpose of the security of the state and its society or organization, and have a special relationship with them. In this context, the concept of security refers primarily, but not exclusively, to external security.

Complexity characterizes the environment in which the military has to complete its missions. Although Stephen Hawking stated that the $21^{\text {st }}$ century would be "the century of complexity", this is not only a $21^{\text {st }}$ century phenomenon. On the contrary, from the perspective of those living in any period of time, the world, the immediate environment and its various manifestations have always been complex. Thus, political and social changes, technological inventions or developments inevitably produce more complexity (Richter \& Rost, 2002). In a systemtheoretical approach, this means that complexity is created by the interconnectedness and the resulting interdependencies of different parts, contributing to the functioning of the overall system at different levels through their individual properties.

Commanders therefore have to find their way around complex systems and act in complex situations. Such situations are unclear or obscure due to the quantity, diversity, and interconnectedness of the elements. This is aggravated by a dynamic which makes such situations subject to change at undefined intervals, which, in turn, makes the handling of complex situations challenging. For example, if a gear wheel is turned, a number of other wheels turn in different directions and the result is difficult to predict.

Acting in and mastering complex situations therefore requires commanders who have diverse skills, such as the ability to think creatively and critically. In order to be able to apply these skills in a situation-appropriate manner, however, a well-founded store of knowledge, which is built up and constantly expanded through formal, non-formal, or informal learning, is an essential prerequisite. These different ways of acquiring knowledge allow the commander to acquire the necessary technical or factual knowledge.

Formal learning is a goal-oriented learning process and takes place in institutions of the education system set up specifically for this purpose. The content is set out in curricular framework plans, with formal qualifications and certifications the products of learning. In contrast to formal learning, non-formal learning and its associated learning locations provide a different form of learning opportunities. Although non-formal learning locations are also characterized by a clear institutional structure and legal framework, they are based on voluntary use within the framework of an open education situation (Harring, Witte \& Burger, 2018). The third way of acquiring knowledge, informal learning, takes place, for example, in the family, in peer groups and in the workplace throughout the course of one's life and can be characterized as a continuation of formal or non-formal learning processes (Lauszus, 2009).

The skills and abilities acquired or appropriated through these learning processes ensure that commanders understand and master their field of expertise, or in other words their 'box'. 
Critical and creative thinking 'outside of the box' is only possible on the basis of such knowledge (Walker, 2015).

\section{Creative Thinking}

Creative thinking is the ability to think in new and original ways, consciously leaving behind traditional or previously used paths to arrive at genuine alternative solutions (Kampylis \& Berki, 2014). This means meeting challenges in a different way, deviating from routine and abandoning preconceived ideas. By experimenting with alternatives, new ideas can be generated, which then lead to novel products or processes (Sutton, 2002). In this sense, ingenuity and creativity, i.e. creative thinking as such, is indispensable and important skills in an increasingly complex world and form the basis of every innovation or further development.

Already in the 1960s, Mel Rhodes, and US-American creativity researcher, formulated four basic elements which make up creativity or creative thinking. These are Personality, Process, Product and Environment and are explained in more detail below.

(1) The personal prerequisites and character traits are a basic condition in order to promote or inhibit creative thinking. These personality traits include the personality itself, the ability to learn and to think, the temperament, habits and behavior of the person (Rhodes, 1961). In this light, openness or sensitivity to new challenges and the mental flexibility associated with them are key components of creative thinking.

However, the most important prerequisite for creativity is the motivation of the individual person to initiate and maintain creative processes. Without this, creativity is theoretically possible, but will not be translated into action (Jacob, 2016). Thus, throughout history, the drive and unrestrained desire for ideas has produced unusual ideas and groundbreaking innovations.
(2) Creative thinking requires a creative process, which ideally includes the phases of preparation, idea generation, idea selection, and idea implementation (Jacob, 2016). The goal is to find unconventional solutions for a specific problem through divergent, open, unsystematic and experimental thinking.

In the preparation phase, problem analysis and definition is carried out in order to determine the initial situation on the one hand and to describe the problem to be solved on the other. Relevant information and available knowledge is collected and systematically arranged. In the subsequent idea generation phase, different ideas are generated by combining the collected information, forming a new structure and generating new knowledge. The application of various creativity techniques supports this phase. In the idea selection phase, the ideas are further developed, specified and structured, and then selected by evaluation methods in order to pick the most promising from the numerous ideas. Finally, the decision is made to implement the most promising solution in reality (Jacob, 2016). If the description of the phases is compared with the military decision making process, commonalities can be identified. It can therefore be deduced that the military decision making process includes or presupposes creative thinking.

(3) The result of the creative creation process is a creative product. This is either an intellectual and immaterial idea or a visible, tangible product or invention.

(4) The existence or creation of a creative environment is essential for creative design. Through this, creativity blockers are counteracted and personal creativity promoted. It has been shown that creativity is directly related to the workplace or the working environment. Firstly, an innovationfriendly or inspiring environment and secondly, a targeted exchange of knowledge can increase creative thinking. 


\section{Critical Thinking}

Through critical thinking, the ability to ask decisive questions or to question given answers consciously is acquired. This in turn leads to insights and new findings.

The promotion of critical thinking is one of the central tasks in higher education. The European Qualifications Framework for Lifelong Learning, for example, makes critical thinking an important target category by stating that "it is considered important to promote critical thinking and thinking outside the box in order to acquire new skills that will be required in the future" (European Parliament, 2017). Pursuant to the European Qualifications Framework, the Federal Act on the National Qualifications Framework came into force on 15 March 2016. This law assigned level 7, i.e. the completion of a Master's degree program, "critical awareness of knowledge issues in a field and at the interface between different fields" as a goal.

This means that graduates of level 7 studies can take on knowledge and insights from various disciplines in order to reflect upon them critically and apply them to their own work. Thus, critical thinking must be included in the curricula and students must be trained and educated in this by appropriate measures.

\section{Implementation in Command Training and Education}

On operations, be they military national defense operations, assistance operations, or international operations, military commanders face complexity. Given the existence of different interest groups, changing alliances, diverse population structures, or diverging national interests, situations and the resulting necessary actions become complex. It is therefore up to the military commanders to critically reflect on their actions with regard to the achievement of objectives and to give new impulses in order to accomplish their missions through creative, innovation-promoting thinking.

For this manner of thinking and acting to be implemented successfully, more attention must be paid to critical and creative thinking in education and training. Even if loyalty, obedience and faithfulness remain essential virtues for a military commander, this does not exclude independent, coherent and rigorous thinking. On the contrary: creative and critical thinking is essential for an organization's successful existence and continuous development. Moreover, this is precisely what military leaders need to be trained in.

This fact was taken into account in the 2012 accreditation application for the University of Applied Sciences Master's Program in Military Leadership. One interdisciplinary qualification states: "Graduates are able to think critically and analytically" and another "Graduates contribute to the realization of organizational goals through creativity and innovation" (Austrian Ministry of Defence, 2012). Thus, the ability to think creatively or critically is formally implemented in the education and training of military commanders.

In terms of creative thinking, students of the University of Applied Sciences Master's Program in Military Command were asked to draw a house. 90\% sketched the standard house they were used to. Although there are countless other types of houses (e.g. high-rise building, tree house, boathouse, etc.), this experiment shows that people leave familiar terrain or ingrained patterns only to a very limited extent in order to engage in something new.

It is therefore essential that creative thinking is specifically promoted in the training of military commanders so that they can consciously leave previous patterns of thought and solutions and 
develop new ones. Therefore, methods and techniques should be used which aim to develop the creative thinking and behavior of the students.

Teachers should provide impulses for reflection and create a space for reflection and subsequent discussion. This, however, requires students to be able to listen, to be inspired and to communicate in a structured manner (Morris, 2006). In this way, students are encouraged to rethink situations and to see approaches from new perspectives, which were not obvious at first.

Critical-analytical thinking is an integral part of good university teaching and is to be trained through the targeted stimulation of students. Students can be introduced to this manner of thinking through the focused use of different media. Short film sequences, for example, can produce doubt and reflection (Jahn, 2013). This can sharpen the view of a certain event or situation. It is essential that structured discussions take place after a period of reflection. In this way, what is seen or experienced is shared with other students, new perspectives are opened up, and a student's individual perception is examined. Such a sequence should be integrated into course planning in order to produce commanders capable of critical thought.

\section{Conclusions}

Acting in complex situations requires new solutions and thus the abandonment of old thinking patterns. It is therefore necessary to train military commanders in creative and critical thinking, to promote this in the execution of their profession, and to actively demand it from their superiors.

As complexity has affected all areas of life and work, problems and challenges identified in the military must also be viewed from different perspectives. This allows new ideas to be combined to create innovative solutions. Critical thinking is the first way to identify problems, as the previous course of action is consciously reflected and questioned. In this sense, it is therefore a prerequisite for creativity.

Military commanders in the age of complexity should and must therefore critically examine their actions with regard to the achievement of objectives. The subsequent creative process leads to innovation and thus to a further development of their own field of expertise in particular and the Armed Forces in general.

\section{REFERENCES}

Austrian Ministry of Defence. (2012). Antrag auf Akkreditierung des FHMasterstudienganges Militärische Führung. Wien: Eigenverlag.

Bousquet, A. (2009). The Scientific Way of Warfare. New York: Columbia University Press.

European Parliament. (2017). Qualifications Framework for lifelong learning, available at: https://www.europarl.europa.eu/doceo/document/TA-8-2017-0217 EN.html, accessed on 22 December 2020.

Farlin, J. (2014). Instruments of National Power: How America Earned Independence. Carlisle: U.S. Army War College.

Gatterer, H. (2017). Die Welt tendiert zur Komplexität, available at: https://www.zukunftsinstitut.de/artikel/die-welt-tendiert-zur-komplexitaet/, accessed on 22 December 2020. 
Harring, M., Witte, M., \& Burger, T. (2018). Informelles Lernen - Eine Einführung. In Harring, M., Witte, M., \& Burger, T. (Eds), Handbuch informelles Lernen (pp. 12-25). Weinheim: Beltz-Juventa.

Hawking, S. (2000). Millennium Interview on January 23, 2000. San Jose Mercury News.

Jacob, N.C. (2016). Kreativität und Innovation. Wiesbaden: Springer Fachmedien.

Jahn, D. (2013). Was es heißt, kritisches Denken zu fördern, available at: https://www.mediamanual.at/mediamanual $/ \mathrm{mm} 2 /$ themen/kompetenz $/ \mathrm{mmt} 1328$ kritischesde nken OK.pdf, accessed on 22 December 2020.

Kampylis, P., \& Berki, E. (2014). Nurturing creative thinking. Genf: International Bureau of Education.

Kümmel, G. (2006). Militärische Aufträge und Legitimation der Streitkräfte. In Gareis, S.B. \& Klein, P. (Eds.), Handbuch Militär und Sozialwissenschaft (pp. 104-111). Wiesbaden: Verlag für Sozialwissenschaften.

Lauszus, T. (2009). Formelles und informelles Lernen - Abgrenzung und Verbindung beider Lernformen. Norderstedt: GRIN-Verlag.

Morris, W. (2006). Creativity - Its Place in Education, available at: http://www.creativejeffrey.com/creative/Creativity in_Education.pdf, accessed on 22 December 2020.

Rhodes, M. (1961). An Analysis of Creativity. Phi Delta Kappan, Vol. 42, No. 7, 305-310.

Richter, K., \& Rost, J.M. (2002). Komplexe Systeme. Frankfurt: Fischer Taschenbuch.

Sutton, R.I. (2002). Weird Ideas that Work. New York, USA: Free Press.

Walker, B. (2015). Thinking outside the Box: How to Think Creatively By Applying Critical Thinking and Lateral Thinking. North Charleston: Create Space Independent Publishing Platform. 